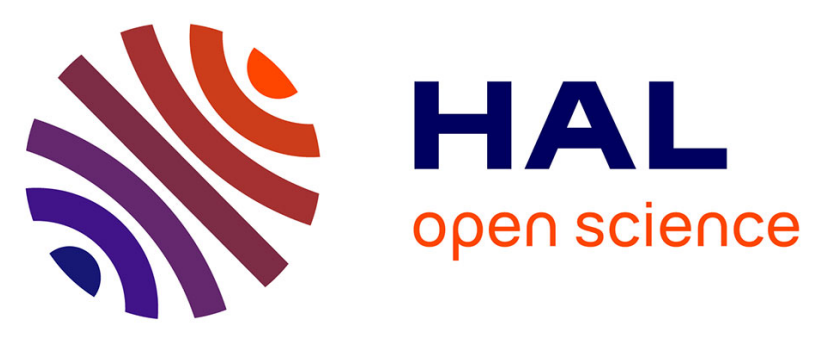

\title{
The behavior of Rare-Earth Elements, Zr and Hf during biologically-mediated deposition of silica-stromatolites and carbonate-rich microbial mats
}

Paolo Censi, M. Cangemi, L. Brusca, P. Madonia, F. Saiano, Pierpaolo Zuddas

\section{- To cite this version:}

Paolo Censi, M. Cangemi, L. Brusca, P. Madonia, F. Saiano, et al.. The behavior of Rare-Earth Elements, Zr and Hf during biologically-mediated deposition of silica-stromatolites and carbonaterich microbial mats. Gondwana Research, 2015, 27 (1), pp.209-215. 10.1016/j.gr.2013.09.014 . hal00873365

\section{HAL Id: hal-00873365 https://hal.science/hal-00873365}

Submitted on 15 Oct 2013

HAL is a multi-disciplinary open access archive for the deposit and dissemination of scientific research documents, whether they are published or not. The documents may come from teaching and research institutions in France or abroad, or from public or private research centers.
L'archive ouverte pluridisciplinaire HAL, est destinée au dépôt et à la diffusion de documents scientifiques de niveau recherche, publiés ou non, émanant des établissements d'enseignement et de recherche français ou étrangers, des laboratoires publics ou privés. 
The behaviour of Rare-Earth Elements, $\mathrm{Zr}$ and $\mathrm{Hf}$ during biologically-mediated deposition of silica-stromatolites and carbonate-rich microbial mats

\author{
Censi P. ${ }^{\text {a,b* }}$, Cangemi M. ${ }^{\mathrm{a}}$, Brusca L. ${ }^{\mathrm{c}}$, Madonia P. ${ }^{\mathrm{c}}$, Saiano F. ${ }^{\mathrm{d}}$, Zuddas P.
}

a) Department of Earth and Marine Sciences, University of Palermo, Via Archirafi, 36 - 90123 Palermo, Italy.

b) IAMC-CNR, UOS di Capo Granitola. Via del mare, 3 - 91026 Cambobello di Mazara, Italy

c) Istituto Nazionale di Geofisica e Vulcanologia, Sezione di Palermo, Via U. La Malfa, 153, 90146 Palermo, Italy.

d) SAF Department, University of Palermo, Viale delle Scienze, 13 - 90128 Palermo, Italy

e) Université Pierre et Marie Curie, Paris 6 Institut des Sciences de la Terre 4, place Jussieu F75005 Paris, France.

* corresponding author: paolo.censi@unipa.it; +3909123861639; +393479662844

\title{
Abstract
}

Venere Lake, in the Pantelleria Island thermal system (Central Mediterranean Sea) consists of a mix of seawater and hydrothermal volcanic fluids containing high levels of dissolved $\mathrm{SiO}_{2}$. Close to the lake's thermal springs, siliceous stromatolites are deposed under high bacterial activity conditions whereas roughly interlaminated $\mathrm{Ca}$-carbonates and microbial mats are widely scattered in the lake. The dissolved REE speciation in lake waters is dominated by $\left[\mathrm{REE}\left(\mathrm{CO}_{3}\right)_{2}\right]^{-}$, $\left[\operatorname{REE}\left(\mathrm{CO}_{3}\right)\right]^{+}$and $\left[\mathrm{REE}\left(\mathrm{H}_{3} \mathrm{SiO}_{4}\right)\right]^{2+}$ complexes. On the contrary the most abundant $\mathrm{Zr}$ and $\mathrm{Hf}$ species are hydroxyl- and fluoride-complexes. The behavior of REE Zr and Hf in the Venere lake waters is controlled by precipitation of amorphous silica, carbonates and bacterial activity. 
Chondrite-normalized REE patterns in stromatolites are characterized by positive La anomalies, superchondritic $\mathrm{Y} / \mathrm{Ho}$ ratios and negative Eu anomalies. The Eu depletion is also found in microbial mats where is associated to a "chondritic" $\mathrm{Y} / \mathrm{Ho}$ signature. $\mathrm{Zr}$ and $\mathrm{Hf}$ differently behave in dissolved phase and in newly-formed siliceous and carbonatic material: Hf reacts easily into amorphous silica surfaces whereas $\mathrm{Zr}$ is preferentially partitioned onto phosphate binding sites on microbial cell surfaces similar to the observed behavior of heavy REE (HREE). We suggest that the $\mathrm{Zr}-\mathrm{Hf}$ relationship reflects the interface processes between mineral phases and bacterial membranes or compounds produced by bacterial activity.

\section{Introduction}

Stromatolites are biogenic rocks formed by bacterial activity in water containing abundant $\mathrm{CO}_{3}{ }^{2}$ ions. Stromatolites are the oldest fossil forms and considered to be proxies for primitive life forms occurring in hostile and extreme environments. Current examples of such extreme environments are thermal zones where hydrothermal water-rock interaction produces large amounts of dissolved $\mathrm{SiO}_{2}$ and deposits stromatolites via cyanobacterial activity (Reid et al., 2000; Olivier and Boyet, 2006). Cangemi et al. (2010) recently showed that siliceous stromatolites form as a consequence of hydrothermal reactions in Pantelleria Island, in the Central Mediterranean. The mechanisms that drive silica precipitation at low temperatures (less than $73^{\circ} \mathrm{C}$ ) have been attributed to the presence of microbial mats (Handley et al., 2005). However, there is no evidence that prokaryotes actively precipitate silica (Konhauser et al., 2004), even if functional groups on their cell walls and within extracellular polymeric substances (EPS) can provide reactive sites for biologically passive silica deposition, followed by autocatalytic silica polymerization (Benning et al., 2004 and references therein).

In this context, microbial activity may play a role in the processes occurring at the solid-liquid interface influencing the distribution of trace elements onto microbial surfaces. Since the late 1980s, many publications have demonstrated that analyzing the geochemical behavior of lanthanides and $\mathrm{Y}$ 
(hereafter defined as REE) is a reliable tool for investigating the processes occurring at the solidliquid interface. In particular, Jehl and Barsczus, 1996; Brantley et al., 2001; Takahashi et al., 2005; 2007 demonstrated that the REE partitioning between bacteria and fluid phases leads to a characteristic REE signature.

The geochemical behavior of REE in the Y-Ho ratio decoupling, now a known process, results from their different electronic configurations, despite their close similarities in terms of ionic charge and radii (see Bau, 1996 for a comprehensive review). Over the past twenty years, Firdaus et al., (2007; 2011), Godfrey et al. (1996; 2008; 2009) have also used the behavior of the Zr-Hf pair as geochemical proxy for the description of weathering and mixing of water masses. In addition, $\mathrm{Zr}-\mathrm{Hf}$ and Y-Ho behave similarly during processes driven by ionic charge and radius (CHARAC processes, Bau, 1996). At the same time, different external electronic configurations $\left([\mathrm{Kr}] 5 s_{0} 4 d_{0}\right.$ and $[\mathrm{Xe}] 4 f_{14} 6 s_{0} 5 d_{0}$ for $\mathrm{Zr}^{4+}$ and $\mathrm{Hf}^{4+}$, respectively) justify the $\mathrm{Zr}-\mathrm{Hf}$ pair decoupling in aqueous nonCHARAC processes and in magmatic systems (Alberti et al., 1999; Bau, 1996; Bau and Alexander, 2009; Comin-Chiaramonti et al., 2007; Firdaus et al., 2011; Frank, 2011).

We still lack knowledge about the geochemical behavior of $\mathrm{Zr}$ and $\mathrm{Hf}$ in processes controlled by microbial activity and related to the deposit of stromatolites under hydrothermal conditions. With our study we aim to fill this gap by analyzing the geochemical behavior of REE, the amplitude of the $\mathrm{Y}$-Ho ratio decoupling and the distribution of $\mathrm{Zr}$ and $\mathrm{Hf}$ concentrations in coexisting siliceous stromatolites and microbial mats during deposition.

\section{Materials and methods}

Pantelleria is a volcanic island in the Central Mediterranean Sea characterized by an active hydrothermal system with fluid emissions at temperatures ranging from 40 to $100^{\circ} \mathrm{C}$.In the northwestern sector, there is an alkaline lake named Venere lake (Fig. 1a). The lake waters are a mixture of rain and seawater plus $\mathrm{CO}_{2}$-dominated hydrothermal fluids with low amounts of $\mathrm{N}_{2}, \mathrm{O}_{2}$, Ar, $\mathrm{CH}_{4}$, and $\mathrm{He}$ (Parello et al., 2000; Gianelli and Grassi, 2001). The balance between external 
input from several sources and the evaporation produces an alkalinisation $(\mathrm{pH} \approx 9)$ with temperatures that follow the seasonal trend (Parello et al., 2000; Cangemi et al., 2010). As a consequence, the lake waters are super-saturated with $\mathrm{Ba}-\mathrm{Ca}$ - and $\mathrm{Mg}$-carbonates, saturated with respect to several silica crystalline polymorphs and slightly under-saturated with respect to amorphous silica (Cangemi et al., 2010). Environmental conditions occurring in the lake water lead to the deposition of siliceous stromatolites associated with microbial mats (Fig. 1b-c). Stromatolites occur in the southwestern lake sector, close to the lake's hydrothermal vents, whereas microbial mats are widely distributed around the entire perimeter of the lake. Both microbial mats and stromatolites show a structure generally consisting of laminated layers, varying in color from orange-red (top) to green (middle part) to reddish-brown (bottom) as a function of different benthic ecosystems. Stromatolites are mineralized microbial mats that consist of centimeter-thick multilayered sequences of microorganisms, mainly bacteria, Archaea and fungi, growing at the interface between the different materials, primarily on moist surfaces that entrap and bind sedimentary grains and precipitate minerals under their direct influence or active secretion.

Microbial mats and stromatolites were collected in very shallow water and placed on a carbon-covered scanning electron microscopy (SEM) mount, spattered with gold/palladium (2 $\times 120 \mathrm{~s}$ at $20 \mathrm{~mA}, 10 \mathrm{~nm}$ coat thickness using an Automatic Spatter Coater) and examined under a field emission scanning electron microscope (Carl Zeiss LEO 1530) at the Department of Geobiology, University of Göttingen (Germany).

To establish the suitable analytical protocol and evaluate precision and accuracy of chemical data, we used the USGS standard reference materials AGV-1 (andesite), MAG (marine mud) and BHVO (basalt). These are considered suitable standard reference materials (SRMs) as they are geological materials with known and certified REE, Zr and Hf concentrations that can be digested with the same simple microwave acid digestion procedure used for samples of siliceous stromatolites. The above-mentioned SRMs consist mainly of sheet silicates, quartz and feldspars (MAG), basaltic glass, pyroxenes, olivine, plagioclase, magnetite (BHVO and AGV) as reported in 
Manheim et al. (1976). Both SRMs and our siliceous stromatolite samples (about $0.2 \mathrm{~g}$ of solid powder) were digested in $12 \mathrm{~mL}$ of freshly prepared aqua-regia solution $\left(\mathrm{HNO}_{3} / \mathrm{HCl}, 1: 3 \mathrm{v} / \mathrm{v}\right)$ and 4 $\mathrm{mL}$ of $\mathrm{HF}$ solution with $2 \mathrm{~g} \mathrm{H}_{3} \mathrm{BO}_{3}$ to complex excess HF. We carried out our data analysis for microbial mats using INCT-OBTL-5 SRM (tobacco leaves from the Poland Institute of Nuclear Chemistry and Technology). We chose INCT-OBTL-5 SRM for its organic matrix similar to that of microbial mats and because its REE and Hf contents are known and certified. Both INCT-OBTL-5 and microbial mat samples (about $0.5 \mathrm{~g}$ of powder solid) were digested in a mixture of $\mathrm{H}_{2} \mathrm{O}_{2}(1.5$ $\mathrm{mL})$ and $\mathrm{HNO}_{3}(3 \mathrm{~mL})$. All the studied SRMs and samples were previously dried $\left(40^{\circ} \mathrm{C}\right)$, powdered in an agate mortar and dissolved in Teflon PFA vessels using a microwave assisted digestion oven (CEM Mars-5). Five different aliquots of each SRM were digested and analyzed to evaluate the errors and accuracies of each element, as reported in supplementary material 1.

All the reagents were Merck ultrapure ${ }^{\mathrm{TM}}$. We diluted and analyzed the obtained solutions using the Inductively Coupled Plasma-Mass Spectrometry (ICP-MS) technique (Agilent 7500ce). All calibration standards and blanks were prepared in the same acid matrix used for the stromatolite samples. Analyses of siliceous stromatolites and microbial mats are reported in supplementary material 2.

Results

SEM images of microbial mats displayed abundant aggregates of microbial colonies of live diatoms, cyanobacteria and densely packed filamentous bacteria embedded in a mostly reticulated organic network formed by a methodologically based degradation of the EPS matrix (Fig. 1d). This matrix is responsible for the gelatinous texture of microbial mats. Electron micrographs of stromatolites revealed a well-structured honeycomb-like organic network constituted of reticulated and shriveled polysaccharide gel derived from the degradation of filamentous and coccoid cyanobacteria, or bacteria (Fig. 1e). The polysaccharide gel acts as a framework providing cohesion in both organic and siliceous materials (Fig. 1d). 
In stromatolites, REEs range between 0.95 and $33.13 \mathrm{mg} \mathrm{kg}^{-1}$. These values are close to those of Proterozoic silica-rich stromatolites (Johan et al., 1995). Stromatolites are REE-depleted in comparison to associated microbial mats, with contents ranging from 13.94 to about $100 \mathrm{mg} \mathrm{kg}^{-1}$. The $\mathrm{Zr}$ and Hf content in stromatolites span from 31.5 to $106 \mathrm{mg} \mathrm{kg}^{-1}$ and from 0.78 to $2.2 \mathrm{mg} \mathrm{kg}^{-1}$ respectively. Microbial mats show higher $\mathrm{Zr}$ and $\mathrm{Hf}$ contents than stromatolites, ranging from 54.23 to $170.39 \mathrm{mg} \mathrm{kg}^{-1}$, and from 0.64 to $2.6 \mathrm{mg} \mathrm{kg}^{-1}$ respectively, consistently with the greater affinity of $\mathrm{Zr}$ and $\mathrm{Hf}$ for biological surfaces (Monji et al., 2008). In both stromatolites and microbial mats, the molar ratios of $\mathrm{Y} / \mathrm{Ho}$ and $\mathrm{Zr} / \mathrm{Hf}$ range from 35 to 303.5 and from 34 to 230, respectively. Y/Ho values are higher in stromatolites with respect to microbial mats. On the contrary, $\mathrm{Zr} / \mathrm{Hf}$ values are usually higher in microbial mats and closer to the chondritic signature in stromatolites.

In the Venere lake waters REE contents are $138.5 \mathrm{ng}^{-1}$ whereas $\mathrm{Zr}$ and $\mathrm{Hf}$ concentrations are 59 and $0.41 \mathrm{ng} \mathrm{l}^{-1} 1$, respectively (C. Inguaggiato, 2013, personal communication). The Y/Ho and $\mathrm{Zr} / \mathrm{Hf}$ molar ratios are 37.9 and 280.7 , respectively. The calculated Y/Ho ratio in lake water is close to that of the microbial mats but is lower than the ratio found in stromatolites. On the contrary, the $\mathrm{Zr} / \mathrm{Hf}$ ratio in lake water is higher compared to that found in both stromatolites and microbial mats. A comparison of $\mathrm{Zr} / \mathrm{Hf}$ and $\mathrm{Y} / \mathrm{Ho}$ values in the studied materials (Fig. 2a) shows that microbial mats and stromatolites have different signatures. The value range for microbial mats defines a horizontal array for $\mathrm{Zr} / \mathrm{Hf}$ between 64.1 and 137.4 (molar ratios) whereas Y/Ho values are clustered around 42.6 \pm 3.2 . Stromatolites, on the other hand, appear to describe an inverse linear array but are in fact scattered and therefore not statistically significant $(\mathrm{Y} / \mathrm{Ho}=-0.47 \mathrm{Zr} / \mathrm{Hf}+291.6 ; \mathrm{r}=0.33)$. In the same graph, $\mathrm{Zr} / \mathrm{Hf}$ and $\mathrm{Y} / \mathrm{Ho}$ values for lake water fall close to the array defined by microbial mats (Fig. 2a). If we consider that the composition of the lake water should be influenced by the deposit of stromatolites and microbial mats, we can add the lake water $\mathrm{Zr} / \mathrm{Hf}$ and $\mathrm{Y} / \mathrm{Ho}$ values to both the stromatolite and the microbial mat arrays (dashed red lines in Fig. 2a). Inconsequence, the stromatolite array slightly changes, increasing its statistical significance to $r=0.93$.

Although statistically unconventional, the observed scenario in Fig. 2a suggests that the lake 
water may represent a common starting point in the evolution of $\mathrm{Zr} / \mathrm{Hf}$ and $\mathrm{Y} / \mathrm{Ho}$ ratios for stromatolites and microbial mats. This scenario is in agreement with the observed different Y-Ho relationships in stromatolites and microbial mats (Fig. 2b). During their deposition, stromatolites preferentially fractionate dissolved $\mathrm{Y}$ onto surfaces of amorphous silica whereas microbial mats are enriched in Ho. The Y-Ho trends in Fig. 2b originate from $\mathrm{Y}$ and Ho contents measured in lake waters.

The differences between the $\mathrm{Zr}-\mathrm{Hf}$ and $\mathrm{Y}$-Ho relationships in microbial mats and stromatolites are highlighted by the chondrite-normalized REE patterns of these materials and their patterns compared with that calculated for the lake water (Fig. 3a). REE anomalies are generally defined as:

$$
\frac{R E E_{i}}{R E E_{i}^{*}}=\frac{2\left[R E E_{i}\right]_{N}}{\left(\left[R E E_{(i 1)}\right]_{N}+\left[R E E_{(i+1)}\right]_{N}\right)}
$$

(Alibo and Nozaki, 1999) where $[\mathrm{REE}]_{\mathrm{N}}$ represents normalized concentrations. [REE $\left.\mathrm{R}_{\mathrm{i}}\right]$, $\left[\mathrm{REE}_{(\mathrm{i}-1)}\right]$ and $\left[\operatorname{REE}_{(\mathrm{i}+1)}\right]$ indicate the $\mathrm{i}^{\text {th }} \mathrm{REE}$ element, the previous and the subsequent ones along the REE series, respectively. As reported in Fig. 3a:

i. Stromatolites are enriched in La, and do not show negative $\mathrm{Ce}$ anomalies (graphically displayed in Fig. 3b). Their chondrite-normalized concentrations from $\mathrm{Gd}$ to $\mathrm{Lu}$ are either constant or increase progressively (Fig. 3c). Their patterns show negative Eu anomalies that are not inherited from lake water composition, where $\mathrm{Eu} / \mathrm{Eu}^{*}=1.1$ (C. Inguaggiato, 2013, personal communication).

ii. Microbial mats are free from La enrichment, showing negative Eu anomalies. Normalized patterns show positive Ce anomalies (graphically displayed in Fig. 3b) and similar features with respect to the lake water composition (Fig. 3a). In microbial mats, normalized REE patterns are characterized by a decrease in concentrations from La to Sm followed by a slight REE depletion along the series from $\mathrm{Gd}$. This suggests that $\mathrm{La} / \mathrm{Gd}$ and $\mathrm{Yb} / \mathrm{Gd}$ ratios are clustered in a narrow value-range, close to that found in lake water and different from those 
calculated for stromatolites (Fig. 3c).

iii. REE distribution in lake water (Fig. 3a) does not show the negative Eu anomaly typical of more evolved volcanic rock outcroppings at Pantelleria (White et al., 2009), suggesting that the observed $\mathrm{Eu}$ enrichment in the water reflects additional processes that have yet to be examined in depth.

\section{Discussion}

\section{REE behavior}

We believe that Y/Ho values, the Y-Ho relationship and the behavior of normalized REE concentrations in lake waters (Fig. 2 and Fig. 3) suggest that the composition of Venere lake can represent the starting point originating the REE distributions in stromatolites and microbial mats. As previously mentioned, the lake water is a mixing of seawater and hydrothermal fluids. The observed positive Eu anomaly of the lake water has to reflect processes occurring directly in the lake rather than effects inherited by rock-water interactions.

Given the chemical physical conditions occurring in the lake, the distribution of the REE speciation abundance can be estimated using the total REE contents the amount of dissolved of $\mathrm{Cl}^{-}$, $\mathrm{F}^{-}, \mathrm{SO}_{4}{ }^{2-}, \mathrm{SiO} 2$ and carbonate species (C. Inguaggiato, 2013, personal communication) by the equation:

$$
\left[R E E_{i} L_{n}^{m \pm}\right]^{(3+n m \pm)}=\left[R E E_{i}\right] \quad\left[L_{n}^{m \pm}\right] \quad \begin{array}{ll}
R E E_{i} \\
L_{n}^{m \pm}
\end{array}
$$

where $\left[\mathrm{REE}_{\mathrm{i}}\right]$ indicates the concentration of the $\mathrm{i}^{\text {th }} \mathrm{REE}$ element, $\left[L_{n}^{m \pm}\right]$ the ligand concentration (H3Sio4-, Cl, CO32_...) and $\underset{L_{n}^{m \pm}}{\left[R E E_{i}\right]}$ the stability constant of the complex. Based on compilations of the stability constants of REE complexes (Millero, 1992; Luo and Byrne, 2004; Migdisov et al., 2009; Akagi, 2013), irrespective of the stability constants used for calculations are referred at ionic strength close to 0 at $25{ }^{\circ} \mathrm{C}$, the distribution of REE species in Venere lake water can be estimate. Fig. 4 shows the values normalized with respect to chondrite to avoid the zig-zag effect. We found 
that the abundance of complex ions in the lake waters display the following decreasing sequence $\left[\operatorname{REE}\left(\mathrm{CO}_{3}\right)_{2}\right]^{-}>\quad\left[\operatorname{REE}\left(\mathrm{CO}_{3}\right)\right]^{+}>\quad\left[\operatorname{REE}\left(\mathrm{H}_{3} \mathrm{SiO}_{4}\right)\right]^{2+}>\quad[\mathrm{REEF}]^{2+}>\quad[\mathrm{REECl}]^{2+}>\quad[\mathrm{REEHCO}]^{2+}>$ $\left[\operatorname{REE}\left(\mathrm{SO}_{4}\right)\right]^{+}$where the more abundant complex show a positive Eu anomaly due to the higher stability of the Eu complexes. Therefore, the observed positive Eu anomaly observed in the water lake is related to the REE speciation with carbonate ions. Normalizing the REE concentration to the composition of lake water we found that Eu anomaly is larger in stromatolite then in siliceous (Fig. 5). Our results are in agreement with the negative Eu anomalies previously observed other carbonate minerals like aragonite (Terakado and Masuda, 1988) and in pegmatite quartz (Gotze et al., 2004).

If REE behave similarly during the deposition of siliceous stromatolites and microbial mats as regards of Eu fractionation, in these materials different $\mathrm{Y}$-Ho relationships are observed that explain the super-chondritic Y/Ho signature of stromatolites with respect to the chondritic Y/Ho values in microbial mats (see Fig. 2b). This different Y-Ho relationship in siliceous stromatolites is consistent with the preferential $\mathrm{Al}^{3+}, \mathrm{Sc}^{3+}, \mathrm{Y}^{3+}, \mathrm{La}^{3+}$ and $\mathrm{Gd}^{3+}$ partitioning on amorphous silica surfaces in chloride medium that Jordan et al. (2011) explained according to a surface complexation energy of these ions strictly related to the decrease of atomic number. Thus, Y would behave as super-light REE explaining the superchondritic Y/Ho value observed in siliceous stromatolites. On the contrary microbial mats that are not 'simple mineral surfaces but cyanobacteria colonies observed in our sample are rich in precipitate Fe-oxyhydroxides (Cangemi et al., 2010), as usually occurs in presence of hydrothermal fluids (Toner et al., 2013). The large Ho sensitivity towards Feoxyhydroxides with respect Y (Bau, 1999) would explain the observed Ho enrichment in microbial mats leading to the chondritic $\mathrm{Y} / \mathrm{Ho}$ values measured in these materials. These results indicate that bacterial activity has minor effects than scavenging onto newly-forming siliceous stromatolites on the Y-Ho fractionation. On the contrary, the preferential medium REE (MREE) binding onto carboxylate sites of EPS biofilms associated to both authigenic materials could contribute to the preferential Eu partitioning in lake water, as previously proposed by Takahashi et al. (2005). The 
lesser Eu reactivity towards surface coordination with respect to its neighbours, could be related to the Eu-binding onto biological surfaces according an outer-sphere mechanism or to the low disposal of phosphate binding sites onto biological surfaces related to REE concentration in coexisting fluid (Takahashi et al., 2010).

\section{Zr and Hf behaviour}

Being the lake water a mix of hydrothermal fluids and seawater, $\mathrm{Zr}$ and $\mathrm{Hf}$ speciations should be dominated by $\left[\mathrm{Me}(\mathrm{OH})_{5}\right]^{-}$complexes. However chloride and fluoride complexes should be no negligible. Based on Eqn. 2 and using the stability constants of fluoride (Monroy-Guzman et al. 2010), chloride- (Aja et al., 1995) and hydrolyl-complexes of $\mathrm{Zr}$ and Hf (Byrne, 2002) at the

physical-chemical conditions occurring in lake water, the $\left[\mathrm{Me}(\mathrm{OH})_{5}\right]^{-}$and $\left[\mathrm{MeF}_{6}\right]^{2-}$ complex ions are the most abundant $\mathrm{Zr}$ and Hf species (Fig. 6).

The $\mathrm{Zr} / \mathrm{Hf}$ ratio of the water lake should reflect the composition of host-rock generally trachytes (congruent dissolution). During diffusion into solids however, Niu (2012) proposed that $\mathrm{Zr}$ and Hf may behave differently as their respective diffusion coefficient may change due to the large different $\mathrm{Zr}$ and $\mathrm{Hf}$ atomic masses. The $\mathrm{Zr} / \mathrm{Hf}$ ratio in trachytes is close to 80 (White et al., 2009) and the expected value $\mathrm{Zr} / \mathrm{Hf}$ ratio of hydrothermal fluids corrected according to Niu (2012) modeling should be close to 110 . Since the average value of the $\mathrm{Zr} / \mathrm{Hf}$ ratio in Mediterranean seawater is close to 100 (Censi et al., 2013), the $\mathrm{Zr} / \mathrm{Hf}$ ratio in water lake should be restricted to the 100-110 range. Inguaggiato and co-workers measured a $\mathrm{Zr} / \mathrm{Hf}$ value of 280 (molar ratio) in lake water (unpublished data) indicating that the deposit of siliceous stromatolites and microbial mats involves preferential $\mathrm{Hf}^{4+}$ removal from the water lake.

The stronger surface-sensitive behavior of $\mathrm{Hf}$ than $\mathrm{Zr}$ suggested in our work is in agreement with Bau and Koschinsky (2006) that observed the preferential Hf removal in Archean chert with respect to coexisting magnetite levels in Tegamani iron formation (Bau and Alexander, 2009). Similar results has been recently found by Firdaus et al., 2011 in the bottom oceanic waters rich in 
silica explained by the Hf removal onto biogenic silica 'Frank, 2011) confirming earlier laboratory work of Takahashi et al. (1999) that found the higher Hf surface-reactivity with respect to $\mathrm{Zr}$ onto amorphous silica at $\mathrm{pH}$ 8. We propose that the silica-based stromatolites and carbonate-rich microbial mats strongly influences $\mathrm{Zr}-\mathrm{Hf}$ behavior in the lake waters of Venere lake system.

\section{Effects of microbial activity on $\mathrm{Zr}$, Hf and REE behaviour}

Bacterial colonies produce extracellular polymeric substances (EPS) consisting of densely packed, multispecies populations, encased in a cell-synthesized polymeric coating bacterial cell surfaces. EPS confer an increasing softness to bacterial surfaces and a negative surface charge due to their anionic nature (Rendueles et al., 2013). These characters provide a very efficient scavenging environment for dissolved metal ions in natural waters due to their polysaccharide composition. In absence of EPS production scavenging of dissolved metal species can directly occurs onto bacterial cell membranes (Moriwaki and Yamamoto, 2013), despite the EPS protective role on bacterial cell (Merroun et al., 1998). Monji et al. (2008) demonstrated the capability of organic matter to preferentially adsorb Zr and Hf with respect REE and other metal ions. Takahashi et al. (2010) demonstrated that binding sites on the cell surface of some bacteria may contain multiple phosphate groups binding HREE preferentially. Alternatively, the HREE enrichment may progressively disappear if the REE coordination onto bacterial cell surfaces occurs via carboxylate O-donor sites as preferentially bind LREE and MREE in alkaline conditions (Takahashi et al., 2010 Fig. 1D). Zr and $\mathrm{Hf}$ speciation based on $\left[\mathrm{Me}(\mathrm{OH})_{5}\right]^{-}$species may increase the surface reactivity of these elements coordinating onto carboxylate sites (see Bau and Koschinsky, 2006 for a comprehensive discussion) according a stronger inner-sphere mechanism. Being $\left[\mathrm{Hf}(\mathrm{OH})_{5}\right]^{-}$complex more stable than $\left[\mathrm{Zr}(\mathrm{OH})_{5}\right]^{-}($Byrne, 2002) and Hf particle-reactivity onto amorphous silica favored with respect Zr (Takahashi et al., 1999), siliceous stromatolites and associated bacterial colonies have slightly lower $\mathrm{Zr} / \mathrm{Hf}$ ratio compared to microbial mats. At the same time, LREE enrichments would be expected in siliceous stromatolites as are preferentially coordinated by carboxylate sites compared 
to HREE (Takahashi et al., 2010). Our data do not allow establishing if these carboxylate sites are provided directly by bacterial surfaces or by polysaccharide EDS chains. However, the observed negative correlations between $\mathrm{La} / \mathrm{Yb}$ and $\mathrm{Zr} / \mathrm{Hf}$ values observed in siliceous stromatolites and microbial mats (Fig. 7) suggest that the preferential LREE scavenging onto authigenic materials is responsible for the observed $\mathrm{Zr} / \mathrm{Hf}$ fractionation. In microbial mats with lower $\mathrm{La} / \mathrm{Yb}$ ratio, the found higher $\mathrm{Zr} / \mathrm{Hf}$ value suggests that microbial mat binding of these elements may occur directly through phosphate groups of bacterial membranes where $\mathrm{Zr}$ to $\mathrm{Hf}$ fractionation is warranted by strong covalent binding between $\mathrm{Zr}$ and phosphate groups (Tan et al., 2013).

\section{Conclusions}

The deposition of siliceous stromatolites and the associated formation of microbial mats drive dissolved REE, Zr and Hf fractionations in waters from the Venere lake in Pantelleria. These consist of a mix of seawater and hydrothermal fluids that delivered to lake waters Silica coming from leaching of trachytic rocks outcropping in the area representing the raw material to precipitate stromatolites. In this general scenario bacterial activity demonstrates to play a crucial role inducing REE fractionations directly onto surfaces of bacterial cells or through the mediation of EPS produced by bacterial colonies. This biogeochemical activity is associated to the different $\mathrm{Y}$-Ho and Zr-Hf reactivity towards surfaces of Fe-oxyhydroxides and amorphous silica, respectively. Although further studies are needed to clarify the biogeochemical role of bacterial colonies to fractionate $\mathrm{Zr}$ and $\mathrm{Hf}$, the $\mathrm{Zr} / \mathrm{Hf}$ ratio steps forward as geochemical proxy of interface fractionation processes together with $\mathrm{Y} / \mathrm{Ho}$. 


\section{Acknowledgements}

The authors are very grateful to M. Bau, to an anonymous reviewer and to P. Eriksson (AE) for their careful and dedicated job of critical revision of the first version of the manuscript. 


\section{References}

Akagi, T., 2013. Rare earth element (REE)-silicic acid complexes in seawater to explain the incorporation of REEs in opal and the "leftover" REEs in surface water: New interpretation of dissolved REE distribution profiles. Geochimica et Cosmochimica Acta 113, 174-192.

Alberti, A., Castorina, F., Censi, P., Comin-Chiaramonti, P., Gomes, C.B., 1999. Geochemical characteristics of Cretaceous carbonatites from Angola. Journal of African Earth Sciences 29, 735759.

Alibo, D.S., Nozaki, Y., 1999. Rare earth elements in seawater: Particle association, shalenormalization, and Ce oxidation. Geochimica et Cosmochimica Acta 63, 363-372.

Bau, M., 1996. Controls on the fractionation of isovalent trace elements in magmatic and aqueous systems: Evidence from $\mathrm{Y} / \mathrm{Ho}, \mathrm{Zr} / \mathrm{Hf}$, and lanthanide tetrad effect. Contributions to Mineralogy and Petrology 123, 323-333.

Bau, M., 1999. Scavenging of dissolved yttrium and rare earths by precipitating iron oxyhydroxide: Experimental evidence for Ce oxidation, Y-Ho fractionation, and lanthanide tetrad effect. Geochimica et Cosmochimica Acta 63, 67-77.

Bau, M., Alexander, B.W., 2009. Distribution of high field strength elements (Y, Zr, REE, Hf, Ta, Th, $\mathrm{U}$ ) in adjacent magnetite and chert bands and in reference standards FeR-3 and FeR-4 from the Temagami iron-formation, Canada, and the redox level of the Neoarchean ocean. Precambrian Research 174, 337-346.

Bau, M., Koschinsky, A., 2006. Hafnium and neodymium isotopes in seawater and in ferromanganese crusts: The "element perspective". Earth and Planetary Science Letters 241, 952961.

Benning, L.G., Phoenix, V.R., Yee, N., Konhauser, K.O., 2004. The dynamics of cyanobacterial silicification: an infrared micro-spectroscopic investigation. Geochimica et Cosmochimica Acta 68, 743-757. 
Brantley, S.L., Liermann, L., Bau, M., Wu, S., 2001. Uptake of trace metals and rare earth elements from hornblende by a soil bacterium. Geomicrobiology Journal 18, 37-61.

Byrne, R.H., 2002. Inorganic speciation of dissolved elements in seawater: The influence of $\mathrm{pH}$ on concentration ratios. Geochemical Transactions 3, 11-16.

Cangemi, M., Bellanca, A., Borin, S., Hopkinson, L., Mapelli, F., Neri, R., 2010. The genesis of actively growing siliceous stromatolites: evidence from Lake Specchio di Venere, Pantelleria Island, Italy. Chemical Geology 276, 318-330.

Censi, P., Raso, M., Saiano, P., Zuddas, P., 2013.Differences between Zr and Hf behaviour in oceans in the light of effects induced by atmospheric fallout in marginal basins. Geochim. Cosmochim. Acta. (submitted).

Comin-Chiaramonti, P., De Barros Gomes, C., Cundari, A., Castorina, F., Censi, P., 2007. A review of carbonatitic magmatism in the Paran $\sqrt{ }^{\circ}$-Angola-Namibia (PAN) system. Periodico di Mineralogia 76, 25-78.

Firdaus, M.L., Minami, T., Norisuye, K., Sohrin, Y., 2011. Strong elemental fractionation of Zr-Hf and Nb-Ta across the Pacific Ocean. Nature Geoscience 4, 227-230.

Firdaus, M.L., Norisuye, K., Sato, T., Urushihara, S., Nakagawa, Y., Umetani, S., Sohrin, Y., 2007. Preconcentration of $\mathrm{Zr}, \mathrm{Hf}, \mathrm{Nb}$, Ta and $\mathrm{W}$ in seawater using solid-phase extraction on TSK-8hydroxyquinoline resin and determination by inductively coupled plasma-mass spectrometry. Analytica Chimica Acta 583, 296-302.

Frank, M., 2011. Oceanography: Chemical twins, separated. Nature Geoscience 4, 220-221.

Gianelli, G., Grassi, S., 2001. Water-rock interaction in the active geothermal system of Pantelleria, Italy. Chemical Geology 181, 113-130.

Godfrey, L.V., Field, M.P., Sherrell, R.M., 2008. Estuarine distributions of Zr, Hf, and Ag in the Hudson River and the implications for their continental and anthropogenic sources to seawater. Geochemistry, Geophysics, Geosystems 9. 
Godfrey, L.V., White, W.M., Salters, V.J.M., 1996. Dissolved zirconium and hafnium distributions across a shelf break in the northeastern Atlantic Ocean. Geochimica et Cosmochimica Acta 60, $3995-4006$.

Godfrey, L.V., Zimmermann, B., Lee, D.C., King, R.L., Vervoort, J.D., Sherrell, R.M., Halliday, A.N., 2009. Hafnium and neodymium isotope variations in NE Atlantic seawater. Geochemistry, Geophysics, Geosystems 10.

Gotze, J., Plotze, M., Graupner, T., Hallbauer, D.K., Bray, C.J., 2004. Trace element incorporation into quartz: A combined study by ICP-MS, electron spin resonance, cathodoluminescence, capillary ion analysis, and gas chromatography. Geochim. Cosmochim. Acta 68, 3741-3759.

Govindaraiu, K., 1984. Compilation of working values and sample description for 170 international reference samples of mainly silicate rocks and minerals. Geostandard newsletter 7, 3-226.

Handley, K.M., Campbell, K.A., Mountain, B.W., Browne, P.R.L., 2005. Abiotic-biotic controls on the origin and development of spicular sinter: in situ growth experiments, Champagne Pool, Waiotapu, New Zealand. Geobiology 3, 93-114.

Jehl, C., Barsczus, H.G., 1996. Origin of rare earth elements in cyanobacterial mats (kopara) from Tikehau atoll (Tuamotu, French Polynesia). Origine des terres rares dans les mattes cyanobact $\sqrt{ }$ Criennes (kopara) de l'atoll de Tikehau (Tuamotu, Polyn $\sqrt{ }(\mathrm{C} s i e$ Fran $\sqrt{ }$ ßaise) 322, 205 212.

Johan, Z., Johan, V., Scharm B., Pouba, Z.,1995. Minéralogie et géochimie des terres rares et du chrome dans les cherts protérozoïques de Kokšín, République Tchèque. Comptes rendus de l'Académie des Sciences 321, 1127-1138.

Jordan, D.S., Saslow, S.A., Geiger, F.M., 2011. Exponential sensitivity and speciation of Al(III), Sc(III), Y(III), La(III), and Gd(III) at fused silica/water interfaces. Journal of Physical Chemistry A $115,14438-14445$

Konhauser, K.O., Jones, B., Phoenix, V.R., Ferris, G., Renaut, R.W., 2004. The Microbial Role in Hot Spring Silicification. Ambio 33(8), 552-558. 
Luo, Y.R., Byrne, R.H., 2004. Carbonate complexation of yttrium and the rare earth elements in natural waters. Geochimica et Cosmochimica Acta 68, 691-699.

Manhein, F.T., Hathaway, J.C., Flanagan F.J., Fletcher, J.D., 1976. Marine mud, MAG-1, from the Gulf of Maine. In: Fletcher, J.D. (ed.), Descriptions and Analyses of Eight New USGS Rock Standards. Geol. Surv. Prof. Paper 840, 25-28.

Merroun, M.L., Ben Omar, N., Gonz ${ }^{{ }^{\circ} l e z-M u} \bigvee_{ \pm}$oz, M.T., Arias, J.M., 1998. Myxococcus xanthus biomass as biosorbent for lead. Journal of Applied Microbiology 84, 63-67.

Migdisov, A.A., Williams-Jones, A.E., Wagner, T., 2009. An experimental study of the solubility and speciation of the Rare Earth Elements (III) in fluoride- and chloride-bearing aqueous solutions at temperatures up to $300 \neg \infty \mathrm{C}$. Geochimica et Cosmochimica Acta 73, 7087-7109.

Millero, F.J., 1992. Stability constants for the formation of rare earth-inorganic complexes as a function of ionic strength. Geochimica et Cosmochimica Acta 56, 3123-3132.

Monji, A.B., Ahmadi, S.J., Zolfonoun, E., 2008. Selective Biosorption of Zirconium and Hafnium from Acidic Aqueous Solutions by Rice Bran, Wheat Bran and Platanus Orientalis Tree Leaves. Separation Science and Technology 43, 597-608.

Monroy-Guzman, F., Trubert, D., Brillard, L., Hussonnois, M., Constantinescu, O., Le Naour, C., 2010. Anion exchange behaviour of $\mathrm{Zr}, \mathrm{Hf}, \mathrm{Nb}$, Ta and $\mathrm{Pa}$ as homologues of $\mathrm{rf}$ and $\mathrm{Db}$ in fluoride medium. Journal of the Mexican Chemical Society 54, 24-33.

Moriwaki, H., Yamamoto, H., 2013. Interactions of microorganisms with rare earth ions and their utilization for separation and environmental technology. Appl. Microbiol. Biotechnol., 97, 1-8.

Niu, Y., 2012. Earth processes cause Zr-Hf and Nb-Ta fractionations, but why and how? RSC Advances 2, 3587-3591.

Olivier, N., Boyet, M., 2006.Rare earth and trace elements of microbialites in Upper Jurassic coraland sponge-microbialite reefs. Chemical Geology 230, 105-123. 
Parello, F., Allard, P., D’Alessandro, W., Federico, C., Jean-Baptiste, P., Catani, O., 2000. Isotope geochemistry of Pantelleria volcanic fluids, Sicily Channel rift: a mantle volatile end-member for volcanism in southern Europe. Earth and Planetary Science Letters 180, 325-339.

Reid, R.P., Visscher, P.T., Decho, A.W., Stolz, J.F., Beboutk, B.M., Dupraz, C., Macintyre, I.G., Paerl, H.W., Pinckney, J.L., Prufert-Beboutk, L., Steppe, T.F., DesMaraisk, D.J., 2000. The role of microbes in accretion, lamination and early lithification of modern marine stromatolites. Nature 406, 989-992.

Rendueles, O., Kaplan, J.B., Ghigo, J.M., 2013. Antibiofilm polysaccharides. Environmental Microbiology 15, 334-346.

Samczyński, Z., Dybczyński, S.R., Polkowska-Motrenko, H., Chajduk, E., Pyszynska, M., Danko, B., Czerska, E., Kulisa, K., Doner, K., Kalbarczyk, P., 2012. Two New Reference Materials Based on Tobacco Leaves: Certification for over a Dozen of Toxic and Essential Elements. The scientific world journal, art. ID 216380, 16 pp.

Takahashi, Y., Châtellier, X., Hattori, K.H., Kato, K., Fortin, D., 2005. Adsoption of rare earth elements onto bacterial cell walls and its implication for REE sorption onto natural microbial mats.Chemical Geology 219, 53-67.

Takahashi, Y., Hirata, T., Shimitu, H., Ozaki, T., Fortin, D., 2007.A rare earth element signature of bacteria in natural water? Chemical Geology 244, 569-583.

Takahashi, Y., Minai, Y., Ambe, S., Makide, Y., Ambe, F., 1999. Comparison of adsorption behavior of multiple inorganic ions on kaolinite and silica in the presence of humic acid using the multitracer technique. Geochimica et Cosmochimica Acta 63, 815-836.

Takahashi, Y., Yamamoto, M., Yamamoto, Y., Tanaka, K., 2010. EXAFS study on the cause of enrichment of heavy REEs on bacterial cell surfaces. Geochimica et Cosmochimica Acta 74, 54435462. 
Tan, P., Lei, C., Liu, X., Qing, M., Nie, Z., Guo, M., Huang, Y., Yao, S., 2013. Fluorescent detection of protein kinase based on zirconium ions-immobilized magnetic nanoparticles. Analytica Chimica Acta 780, 89-94.

Terakado, Y., Masuda, A., 1988. Coprecipitation of Rare-Earth Elements with calcite and aragonite. Chem. Geol. 69, 103-110.

Toner, B.M., Lesniewski, R.A., Marlow, J.J., Briscoe, L.J., Santelli, C.M., Bach, W., Orcutt, B.N., Edwards, K.J., 2013. Mineralogy Drives Bacterial Biogeography of Hydrothermally Inactive Seafloor Sulfide Deposits. Geomicrobiology Journal 30, 313-326.

White JC, Parker DF, Ren M., 2009. The origin of trachyte and pantellerite from Pantelleria, Italy: Insights from major element, trace element, and thermodynamic modelling. J Volcanol Geoth Res $179,33-55$. 


\section{Figure captions}

Figure 1 - a) Map of Pantelleria Island (Italy) showing the location of lake Specchio di Venere (black square); b) field photograph of microbial mats; c) field photograph of submerged siliceous stromatolites; $\mathrm{d}-\mathrm{f}$ ) electron micrographs of microbial mats showing colonies of cyanobacteria embedded in a reticulated organic matter network; (d) diatoms entrapped in degraded extracellular polymeric substances and (e) siliceous stromatolites with a broad reticulated organic network that acts as framework for the structure (f).

Figure 2 - (a): Zr-Hf (a) and Y-Ho (b) relationships in stromatolites (circles), microbial mats (dots) and water of Venere Lake (red asterisk) the linear trends are calculated considering the composition of lake water. (b): Y-Ho relationships in stromatolites and microbial mats.

Figure 3 - (a): Chondrite-normalized REE patterns of studied materials; (b): distributions of Ce and $\operatorname{Pr}$ anomaly values $\left(\mathrm{Ce} / \mathrm{Ce}^{*}\right.$ and $\mathrm{Pr} / \mathrm{Pr}$, respectively) in studied stromatolites and microbial mats. Field I: prevailing positive Ce anomalies. Field II: prevailing positive La anomalies. From Bau and Dulski (1996) modified. (c): Features of chondrite-normalised patterns in studied materials according to $\mathrm{La} / \mathrm{Gd}$ and $\mathrm{Yb} / \mathrm{Gd}$ normalised ratios. Symbols as in Fig. 2.

Figure 4 - Calculated concentrations of most abundant REE complexes in Venere lake water. Values are normalised to chondrite. For further details see text.

Figure 5 - Patterns depicting REE concentrations in stromatolites and microbial mats normalised to the composition of lake water.

Figure 6 - Calculated concentrations of most abundant $\mathrm{Zr}$ and $\mathrm{Hf}$ complexes in Venere lake water. Figure 7 - Relationship between $\mathrm{La} / \mathrm{Yb}$ normalised ratio and $\mathrm{Zr} / \mathrm{Hf}$ reporting the progressive growth of $\mathrm{Zr}$ contents in stromatolites and microbial mats with the progressive HREE partitioning in these materials. The statistical significance of reported linear trends occur for $\alpha=0.1$ (siliceous stromatolites) and $\alpha=0.05$ (microbial mats). Symbols as in Fig. 2. 


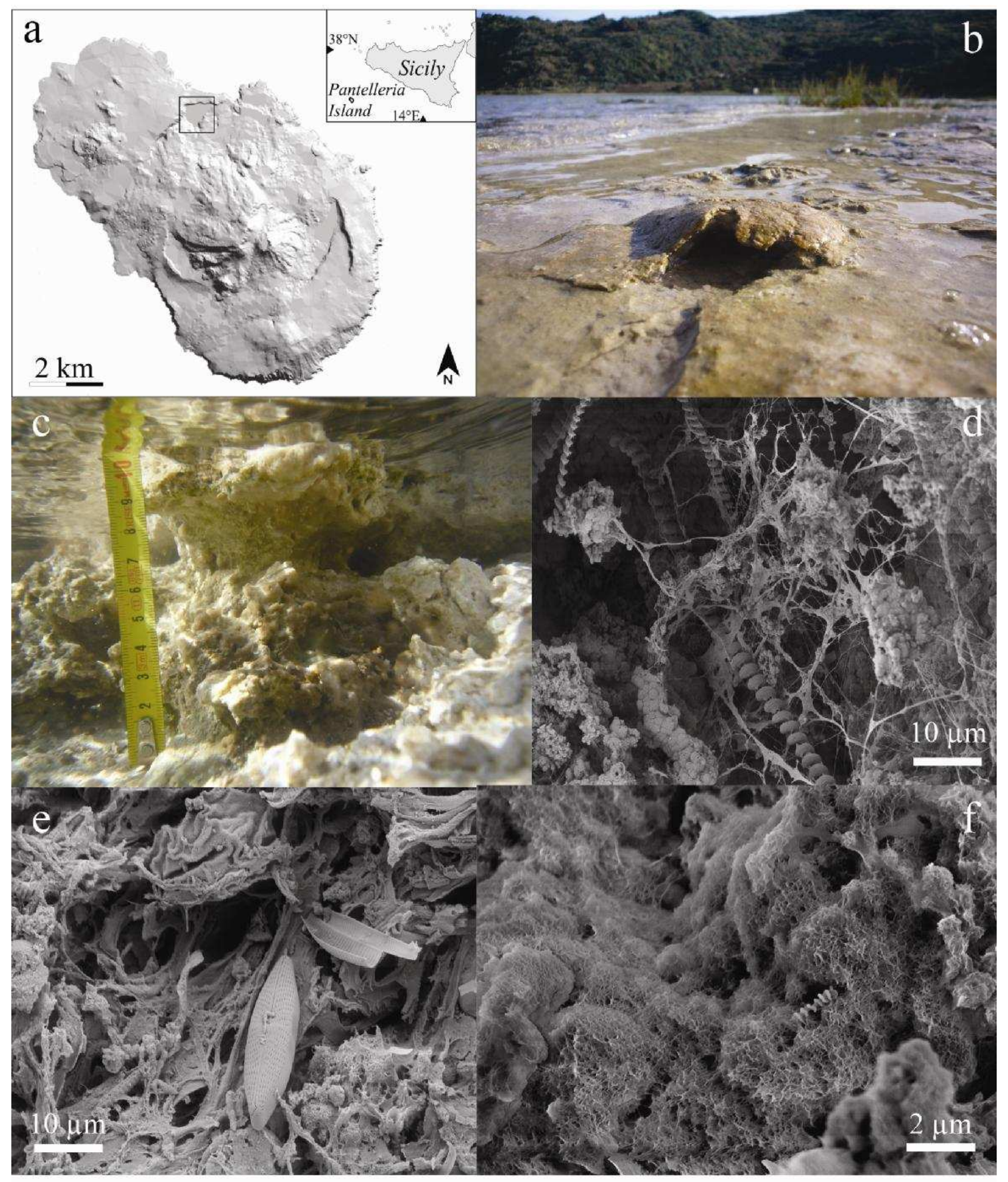

Fig. 1 

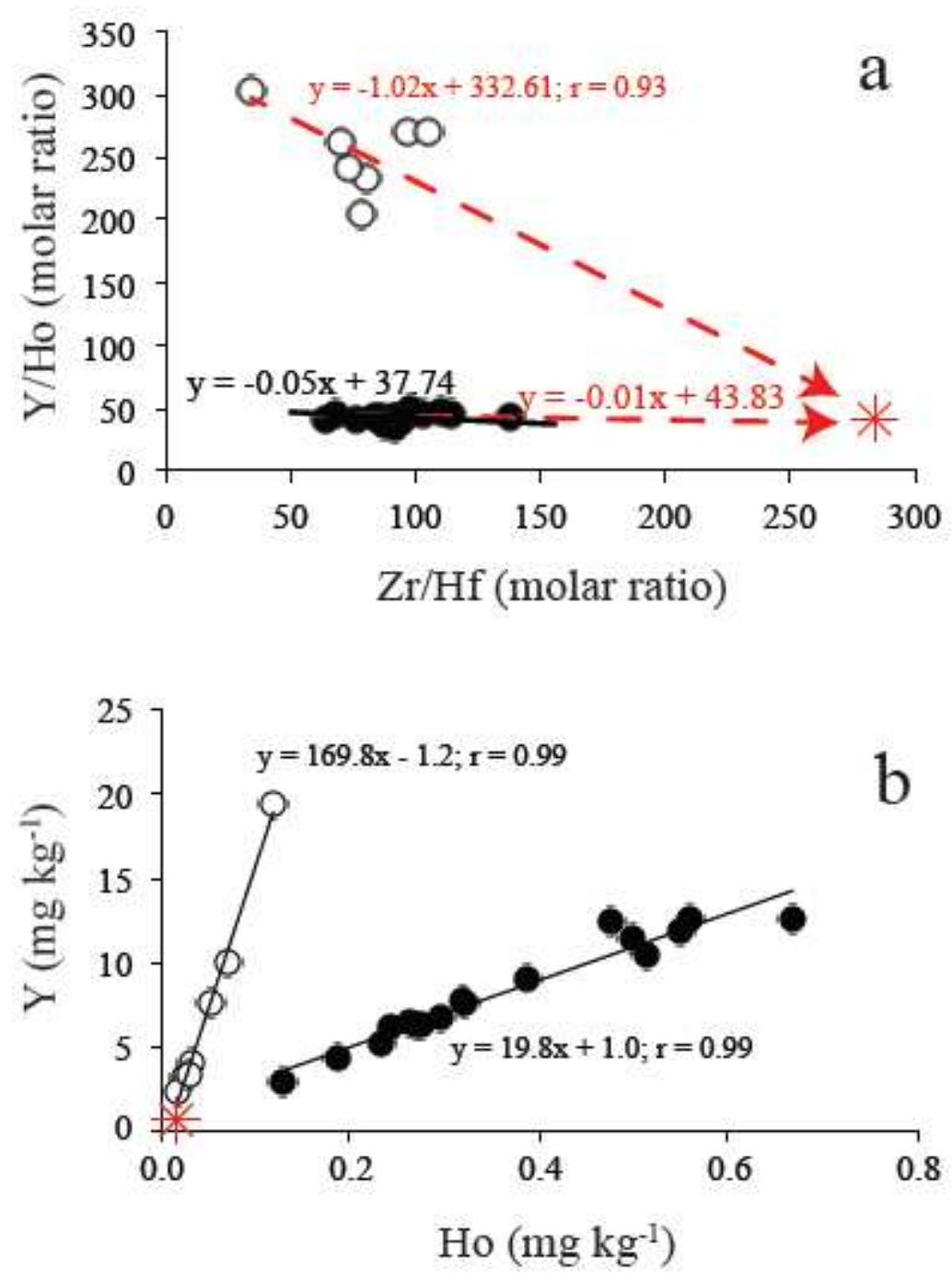

Fig. 2 

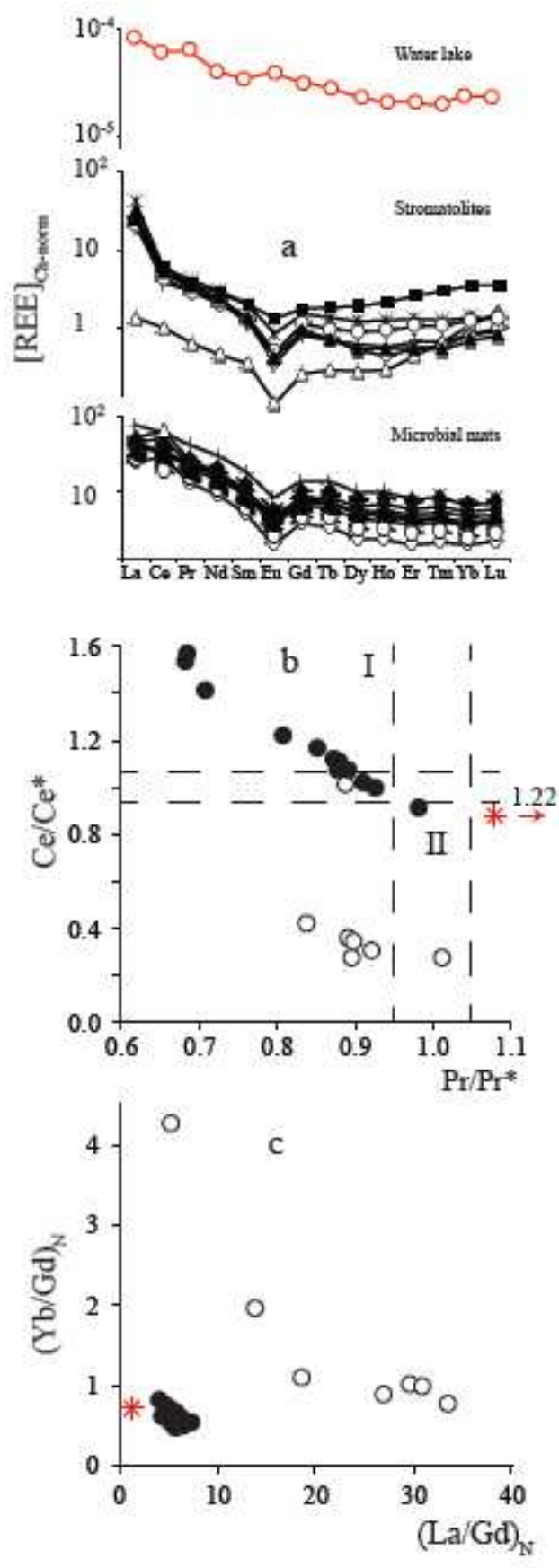

Fig. 3 


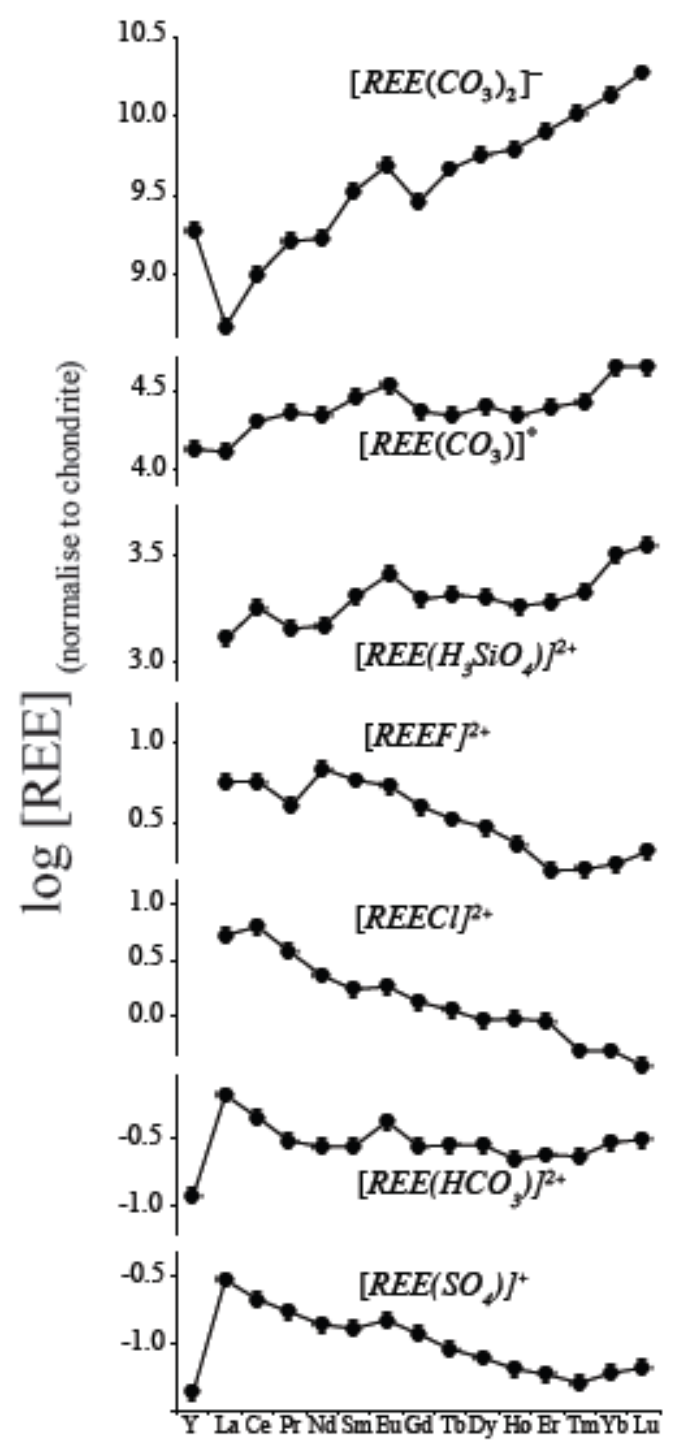

Fig. 4 


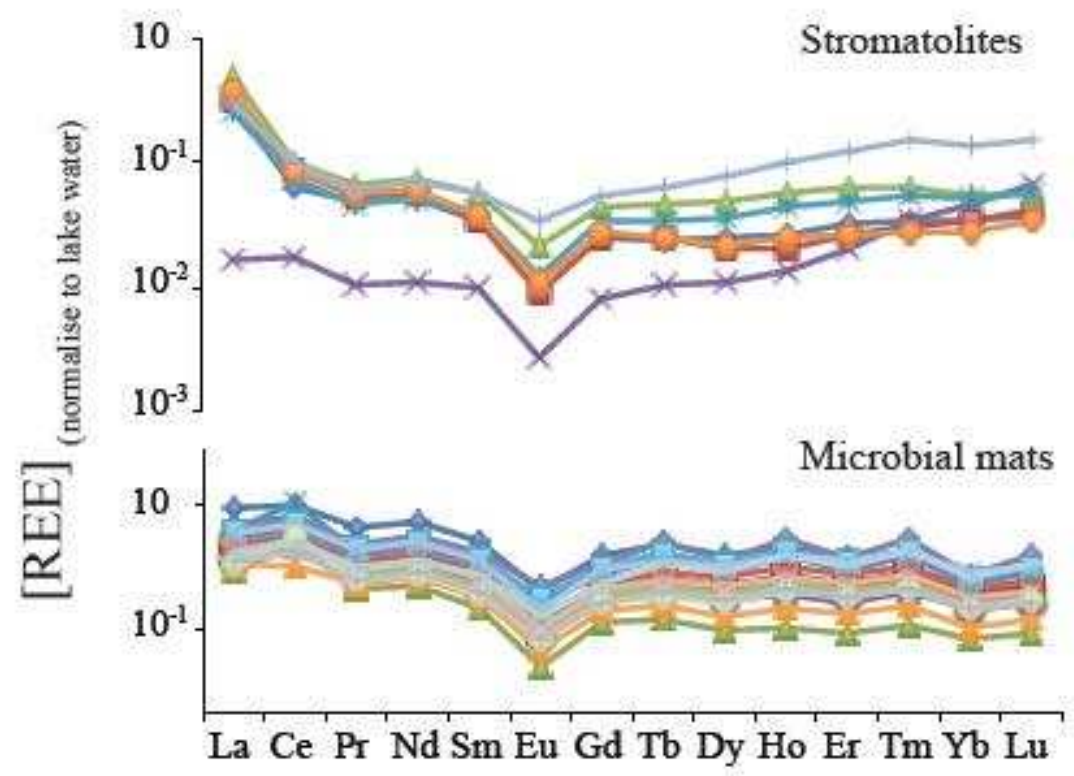

Fig. 5 


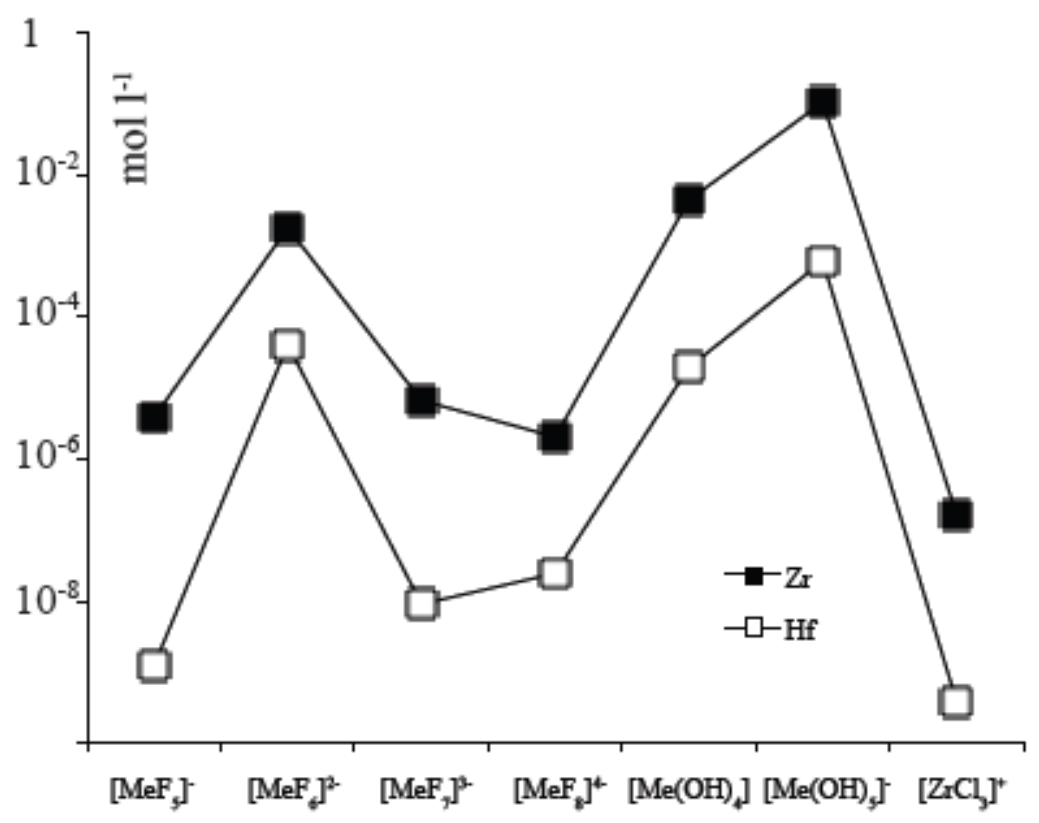

Fig. 6 


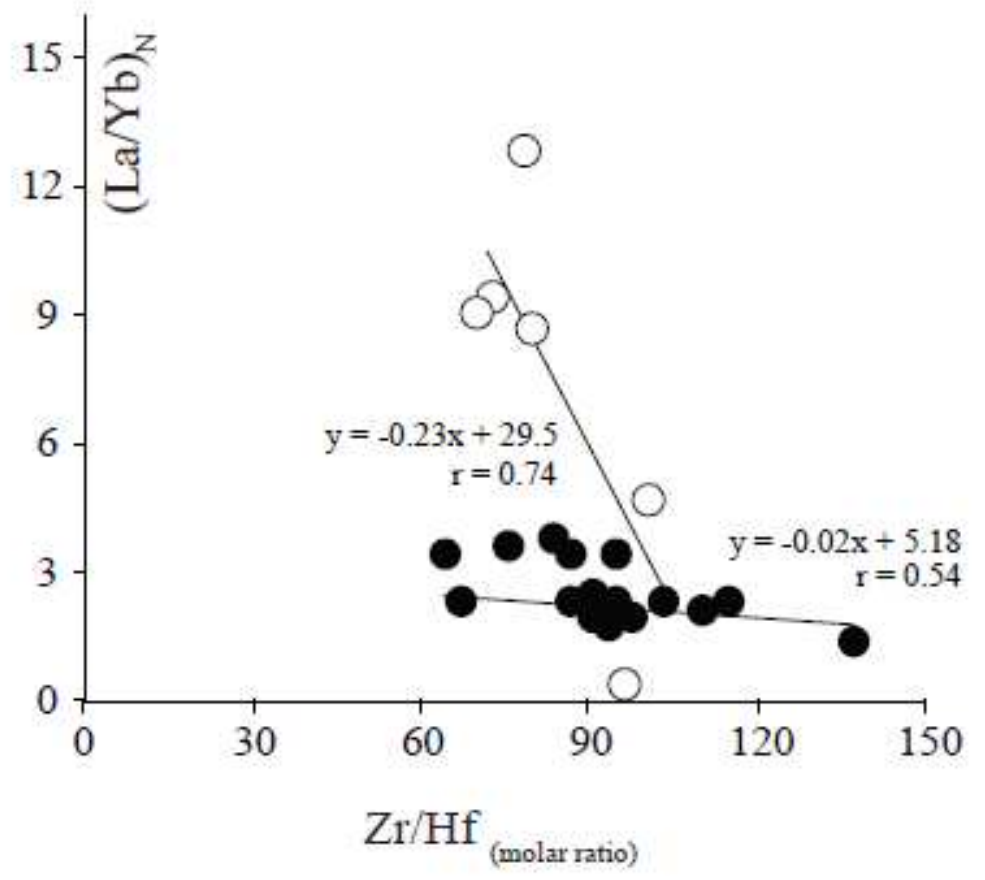

Fig. 7 


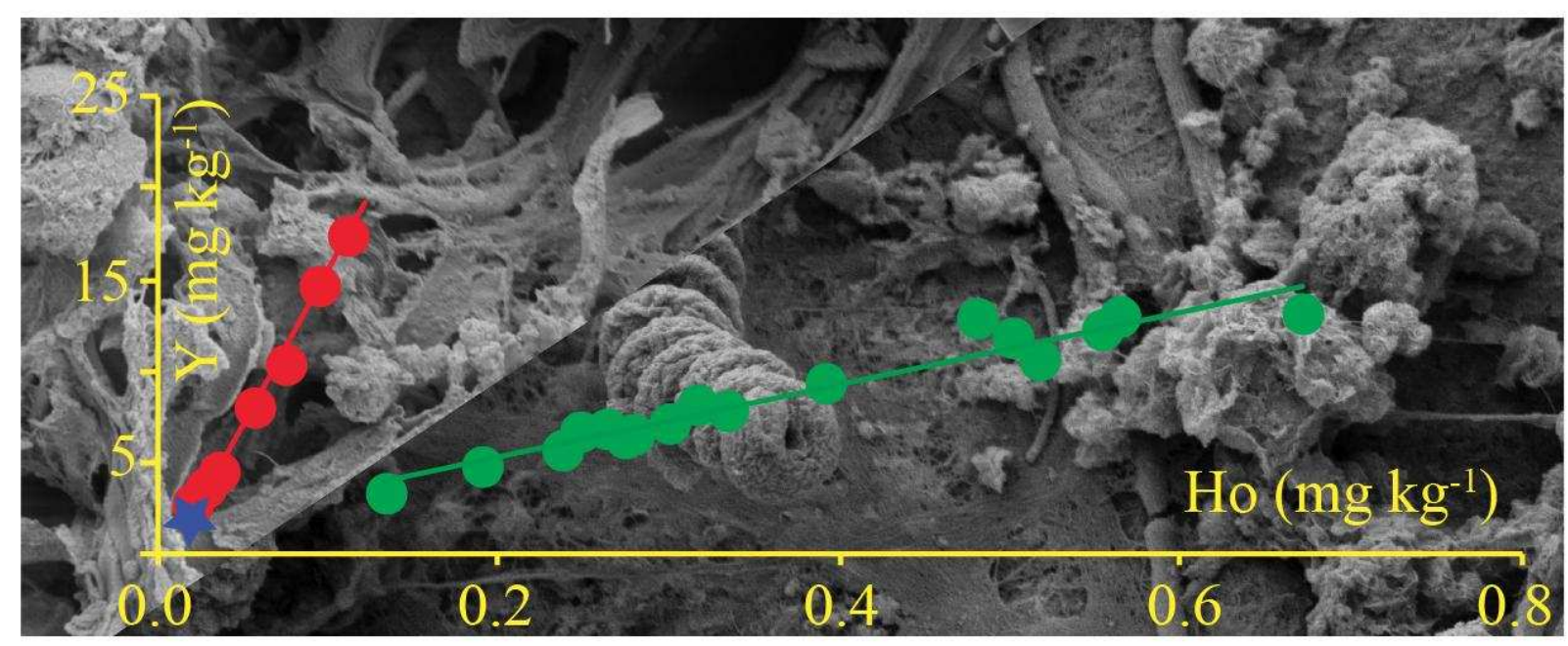

Graphical abstract 
Highlights

- Scavenging onto $\mathrm{SiO}_{2}$ and bacterial surfaces drive aqueous REE, $\mathrm{Zr}$ and Hf contents

- Eu is enriched in waters with respect to its neighbours at solid-liquid interface

- Amorphous $\mathrm{SiO}_{2}$ is more reactive towards $\mathrm{Zr}$ and biological surfaces towards $\mathrm{Hf}$ 